\title{
Polymorphisms of the XRCCI, XRCC3 and XPD genes and risk of colorectal adenoma and carcinoma, in a Norwegian cohort: a case control study
}

\author{
Camilla Furu Skjelbred 1,2, Mona Sæbø², Håkan Wallin³, \\ Bjørn Andersen Nexø ${ }^{4}$, Per Christian Hagen ${ }^{2}$, Inger Marie Bowitz Lothe ${ }^{5}$, \\ Steinar Aase ${ }^{6}$, Egil Johnson 7 , Inger-Lise Hansteen ${ }^{1}$, Ulla Vogel ${ }^{3}$ and \\ Elin H Kure*2,5
}

\begin{abstract}
Address: ${ }^{1}$ Department of Laboratory Medicine, Section of Medical Genetics, Telemark Hospital, N-3710 Skien, Norway, ${ }^{2}$ Telemark University College, Faculty of Arts and Sciences, Department of Environmental and Health Studies, Hallvard Eikas plass, N-3800 Bø i Telemark, Norway, ${ }^{3}$ National Institute of Occupational Health, Copenhagen, Denmark, ${ }^{4}$ Institute of Human Genetics, University of Aarhus, Aarhus, Denmark, ${ }^{5}$ Department of Pathology, Ullevaal University Hospital, Oslo, Norway, ${ }^{6}$ Department of Pathology, The Gade Institute, Haukeland University Hospital / University of Bergen, N-5021 Bergen, Norway and ${ }^{7}$ Department of Gastroenterological Surgery, Ullevaal University Hospital, Oslo, Norway

Email: Camilla Furu Skjelbred - camilla-furu.skjelbred@sthf.no; Mona Sæbø - mona.sabo@hit.no; Håkan Wallin - hwa@ami.dk; Bjørn Andersen Nexø - nexo@humgen.au; Per Christian Hagen - per.chr.hagen@ hit.no; Inger Marie Bowitz Lothe - ingermariebowitzlothe@ulleval.no; Steinar Aase - steinar.aase@helse-bergen.no; Egil Johnson - egil.johnson@ulleval.no; IngerLise Hansteen - inger-lise.hansteen@sthf.no; Ulla Vogel - ubv@ami.dk; Elin H Kure* - elin.kure@hit.no

* Corresponding author
\end{abstract}

Published: 16 March 2006

BMC Cancer2006, 6:67 doi:10.1 186/147/-2407-6-67
Received: 23 November 2005

Accepted: 16 March 2006

This article is available from: http://www.biomedcentral.com/147/-2407/6/67

(c) 2006Skjelbred et al; licensee BioMed Central Ltd.

This is an Open Access article distributed under the terms of the Creative Commons Attribution License (http://creativecommons.org/licenses/by/2.0), which permits unrestricted use, distribution, and reproduction in any medium, provided the original work is properly cited.

\begin{abstract}
Background: Genetic polymorphisms in DNA repair genes may influence individual variation in DNA repair capacity, which may be associated with risk of developing cancer. For colorectal cancer the importance of mutations in mismatch repair genes has been extensively documented. Less is known about other DNA repair pathways in colorectal carcinogenesis. In this study we have focused on the $X R C C I, X R C C 3$ and $X P D$ genes, involved in base excision repair, homologous recombinational repair and nucleotide excision repair, respectively.
\end{abstract}

Methods: We used a case-control study design ( 157 carcinomas, 983 adenomas and 399 controls) to test the association between five polymorphisms in these DNA repair genes (XRCCI Arg ${ }^{194} \mathrm{Trp}$, $\mathrm{Arg}{ }^{280} \mathrm{His}$, Arg ${ }^{399} \mathrm{Gln}$, XRCC3 $\mathrm{Thr}^{241}$ Met and XPD Lys ${ }^{75} \mathrm{G} \mathrm{G}$ ), and risk of colorectal adenomas and carcinomas in a Norwegian cohort. Odds ratio (OR) and $95 \%$ confidence interval $(95 \% \mathrm{Cl})$ were estimated by binary logistic regression model adjusting for age, gender, cigarette smoking and alcohol consumption.

Results: The XRCCI 280His allele was associated with an increased risk of adenomas (OR 2.30, 95\% CI I.19-4.46). The XRCCI $399 \mathrm{Gln}$ allele was associated with a reduction of risk of high-risk adenomas (OR $0.62,95 \% \mathrm{Cl} 0.4 \mathrm{I}-0.96)$. Carriers of the variant XPD 75 I Gln allele had an increased risk of low-risk adenomas (OR I.40, $95 \% \mathrm{Cl} \mathrm{I.03-I.89),} \mathrm{while} \mathrm{no} \mathrm{association} \mathrm{was} \mathrm{found} \mathrm{with}$ risk of carcinomas.

Conclusion: Our results suggest an increased risk for advanced colorectal neoplasia in individuals with the XRCCI Arg ${ }^{280} \mathrm{His}$ polymorphism and a reduced risk associated with the XRCCI $\mathrm{Arg}^{399} \mathrm{Gln}$ polymorphism. Interestingly, individuals with the XPD Lys ${ }^{75 I}$ Gln polymorphism had an increased risk of low-risk adenomas. This may suggest a role in regression of adenomas. 


\section{Background}

In Western populations the vast majorities of colorectal cancers (CRC) arise from benign adenomatous polyps (colorectal adenomas) and evolve through the adenomacarcinoma sequence, a multistep process of genetic alterations $[1,2]$. The lifetime risk of CRC in a normal population is low in comparison to the prevalence of adenomas. This indicates that only a few of the adenomas will develop into a carcinoma. However, from the perspective of understanding the genetic events involved in colonic neoplasia, these early lesions are valuable endpoints.

The risk of sporadic CRC is associated with lifestyle factors like cigarette smoking and alcohol consumption which may be modulated by several genetic factors of low penetrance $[3,4]$. Cigarette smoke and alcohol may act as sources of chemical carcinogens (including nitrosamines, heterocyclic amines and polycyclic hydrocarbons), reactive oxygen species (ROS) [5,6] and DNA adduct formation [3]. Genetic polymorphisms in DNA repair genes may influence individual variation in DNA repair capacity, which may be associated with risk of developing cancer [7]. During the past years, an increasing number of DNA repair gene polymorphisms have been described and their involvement in carcinogenesis investigated. For colorectal cancer, the importance of mutations in mismatch repair (MMR) genes has been extensively documented. Less is known about other DNA repair pathways in colorectal carcinogenesis, and in this study we have focused on the XRCC1, XRCC3 and XPD genes.

The DNA repair gene XRCC1 gene codes for a protein involved in the repair of single-strand breaks (SSB) and in base excision repair (BER) of damaged bases caused by endogenous and exogenous oxidants. Three polymorphisms occurring at conserved sequences in the XRCC1 gene were reported by Shen et al. [8]. These coding polymorphisms, resulting in amino acid substitutions, were detected at codons 194 (Arg-Trp), 280 (Arg-His) and 399 (Arg-Gln). Most studies report a reduced risk of cancer associated with the 194Trp allele [9]. The 399 polymorphism have been associated with a number of cancers, although results have been inconsistent [9-15]. Few studies have investigated the association between the XRCC1 280 His allele and risk of cancer. No association has been observed with colorectal cancer [13], but an increased risk has been reported with lung cancer [16] and breast cancer [17].

The XRCC3 gene codes for a protein involved in homologous recombinational repair (HRR) of double-strand DNA and is required for genomic stability [18,19]. The XRCC3 gene has a sequence variation in exon 7 (C18067T), which results in an amino acid substitution at codon 241 (Thr ${ }^{241} \mathrm{Met}$ ) that may affect the enzyme's func- tion and/or its interaction with other proteins involved in DNA damage and repair [20]. Molecular epidemiological studies have linked this XRCC3 polymorphism to increased risk of breast cancer [21], lung cancer [22], skin cancer [23] and colorectal cancer [14]. The results have been inconsistent [24].

The XPD protein is involved in the nucleotide excision repair (NER) pathway [25], which recognizes and repairs a wide range of structurally unrelated lesions such as bulky adducts and thymidine dimers [26-28]. The XPD gene encodes a helicase that is a component of the transcription factor TFIIH [29]. Mutations in the XPD gene can diminish the activity of TFIIH complexes increasing the likelihood of repair defects, transcription defects, and abnormal responses to apoptosis [30]. The XPD Lys ${ }^{751} \mathrm{Gln}$ substitution is attributed to a $(\mathrm{A} \rightarrow \mathrm{C})$ transversion at exon 23 [8]. Several epidemiological studies have investigated the association between XPD polymorphisms and cancer. Smoking related cancers and skin cancers are most frequently investigated, but it is not yet established whether the polymorphism is linked to risk of lung cancer [31,32]. No association has been observed with the various stages of the adenoma-carcinoma sequence or with colorectal cancer $[14,15]$.

In the present study we used a case-control design to test the association between five amino acid substitution variants of DNA repair genes, XRCC1 (Arg ${ }^{194}$ Trp), XRCC1 (Arg $\left.{ }^{280} \mathrm{His}\right)$, XRCC1 (Arg $\left.{ }^{399} \mathrm{Gln}\right)$, XRCC3 (Thr ${ }^{241} \mathrm{Met}$ ) and $X P D\left(\right.$ Lys $\left.^{751} \mathrm{Gln}\right)$, and colorectal adenoma/cancer risk in a Norwegian cohort. The main focus was to investigate if these polymorphisms are linked to risk of colorectal adenoma and carcinoma. By studying repair genes in the various stages of the adenoma-carcinoma sequence we may gain new information on the significance of polymorphisms in neoplastic tissues during transition.

\section{Methods}

The cohort in the KAM (Kolorektal cancer, Arv og Miljø) molecular epidemiological study is based on the screening group of the Norwegian Colorectal Cancer Prevention study (The NORCCAP study) in the county of Telemark [33]. The ID number for the NORCCAP study at ClinicalTrials.gov is NCT00119912 [34]. In addition, patients diagnosed with colorectal cancer, operated on at Telemark Hospital (Skien) and Ulleval University Hospital (Oslo) were included. The KAM cohort is based on an ethnic homogeneous group of Norwegian origin.

The KAM biobank consists of blood and tissue samples from 1044 individuals identified with adenomas in the large intestine (991 high- and low-risk adenomas, 53 hyperplastic polyps), 160 with colorectal cancer and 400 controls, defined as individuals with normal findings at 
Table I: Distributions of age, gender, cigarette smoking and alcohol consumption among controls and cases with colorectal carcinomas and adenomas.

\begin{tabular}{|c|c|c|c|c|c|}
\hline & Controls & Carcinomas & Adenomas, all & $\begin{array}{l}\text { High-risk } \\
\text { adenomas }\end{array}$ & Low-risk adenomas \\
\hline & No (\%) & No (\%) & No (\%) & No (\%) & No (\%) \\
\hline No. of subjects & 399 & 157 & 983 & 227 & 756 \\
\hline \multicolumn{6}{|l|}{ Gender ${ }^{\mathbf{a}}$} \\
\hline Male & $157(39.3)$ & $87(55.4)$ & $603(6 \mid .3)$ & $150(66.1)$ & $453(59.9)$ \\
\hline Female & $242(60.7)$ & $70(44.6)$ & $380(38.7)$ & 77 (33.9) & $303(40.1)$ \\
\hline \multicolumn{6}{|l|}{ Age $^{b}$} \\
\hline Mean (SD) & $54.2(3.3)$ & $67.9(11.2)$ & $57.3(3.7)$ & $57.3(3.5)$ & $57.3(3.8)$ \\
\hline \multicolumn{6}{|l|}{ Smoking status * } \\
\hline Never smoked & $155(46.7)$ & $33(31.1)$ & $253(30.6)$ & $51(27.0)$ & $202(31.7)$ \\
\hline Ever smoked & $177(53.3)$ & $73(68.9)$ & $574(69.4)$ & $138(73.0)$ & $436(68.3)$ \\
\hline $\begin{array}{l}\text { Mean no. of cigarette } \\
\text { years (SD) }\end{array}$ & $249(229)$ & $383(339)$ & $360(263)$ & $389(244)$ & $35 I(269)$ \\
\hline \multicolumn{6}{|c|}{ Alcohol consumption * } \\
\hline$<$ I unit/month & $72(21.7)$ & $36(34.0)$ & $180(21.8)$ & $43(22.8)$ & $137(2 \mid .5)$ \\
\hline$\geq \mathrm{I}$ unit/month & $260(78.3)$ & $70(66.0)$ & 647 (78.2) & 146 (77.2) & $501(78.5)$ \\
\hline $\begin{array}{l}\text { Mean units of alcohol } \\
\text { per month (SD) }\end{array}$ & II.I (12.2) & $15.5(22.3)$ & $16.4(22.9)$ & $18.4(29.8)$ & $15.8(20.4)$ \\
\hline
\end{tabular}

* Missing values for cigarette smoking and alcohol consumption gave rise to diminished number of cases and controls.

a There are significant differences in the number of males and females in the control group and the case groups, $\mathrm{p}<10^{-4}$ (test for comparison of two proportions).

b There are significant differences in age among the control group and the case groups, $\mathrm{p}<10^{-4}$ (Mann-Whitney test).

flexible sigmoidoscopy screening. All of the participants completed a questionnaire on demographics, health status, dietary; and smoking habits, alcohol consumption, physical exercise and occupation. The questionnaire contained information on a family history of adenomas and carcinomas, and the included cases and controls had no known personal history of genetic predisposition. The KAM study is approved by the Regional Ethics Committee and the Data Inspectorate.
In the present study we analyzed available blood samples from 157 cases with carcinoma, 983 cases with adenomas, (i.e. 227 high-risk and 756 low-risk adenomas) and 399 controls. A high-risk adenoma is defined as an adenoma measuring $\geq 10 \mathrm{~mm}$ in diameter and/or with villous components and/or showing severe dysplasia [33].

The distribution of age, gender, cigarette smoking and alcohol consumption among controls and cases with colonic carcinomas and adenomas are shown in Table 1.

Table 2: Design of primers and TaqMan probes for allelic discrimination assay.

\begin{tabular}{|c|c|}
\hline Primer /Probe & Sequence \\
\hline \multicolumn{2}{|l|}{$X R C C I$ codon 194} \\
\hline Forward primer: & 5'-GAG GAT GAG AGC GCC AAC TC-3' \\
\hline Reverse primer: & 5'-TCA CTC AGG ACC CAC GTT GTC-3' \\
\hline Probe $C$ allele: & 5'-VIC-TCT TCA GCC GGA TCA-MGB/NFQ-3' \\
\hline Probe $\mathrm{T}$ allele: & 5'-FAM-TCT TCA GCIGGA TCA A-MGB/NFQ-3' \\
\hline \multicolumn{2}{|l|}{$X R C C I$ codon 280} \\
\hline Forward primer: & 5'-GGT GCT AAC CTA ATC TAC TCT TTG TCT TC-3' \\
\hline Reverse primer: & 5'-TGG GCT CGG TGC CTT CT-3' \\
\hline Probe $\mathrm{G}$ allele: & 5'-VIC-AGC TCC AAC TCG TAC C-MGB/NFQ-3' \\
\hline Probe A allele: & 5'-FAM-AGC TCC AAC TCA TAC C-MGB/NFQ-3' \\
\hline \multicolumn{2}{|l|}{$X R C C I$ codon 399} \\
\hline Forward primer: & 5'-GAG TGG GTG CTG GAC TGT CA-3' \\
\hline Reverse primer: & 5'-CAT TGC CCA GCA CAG GAT AA-3' \\
\hline Probe $\mathrm{G}$ allele: & 5'-VIC-CCT CCC GGA GGT AA-MGB/NFQ-3' \\
\hline Probe $A$ allele: & 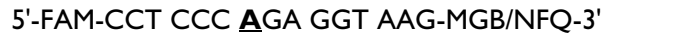 \\
\hline
\end{tabular}

The bold underlined letters represent the polymorphic positions. 
Table 3: Distributions of XRCCI Arg ${ }^{194} \mathrm{Trp}$, XRCCI Arg ${ }^{280} \mathrm{His}$, XRCCI Arg ${ }^{399} \mathrm{GIn}$, XRCC3 Thr ${ }^{241}$ Met and XPD Lys ${ }^{751}$ GIn genotypes and development of colorectal carcinomas and adenomas. $O R s$ are adjusted for age.

\begin{tabular}{|c|c|c|c|c|c|c|c|c|c|}
\hline Genotypes & Controls & Carcinomas & OR $(95 \% \mathrm{Cl})$ & Adenomas & OR $(95 \% \mathrm{Cl})$ & $\begin{array}{c}\text { High-risk } \\
\text { adenoma } \\
\text { s }\end{array}$ & OR $(95 \% \mathrm{Cl})$ & $\begin{array}{l}\text { Low-risk } \\
\text { adenomas }\end{array}$ & OR $(95 \% \mathrm{Cl})$ \\
\hline \multicolumn{10}{|l|}{ XRCCI Arg ${ }^{194}$ Trp } \\
\hline $\operatorname{Arg} / \operatorname{Arg}(\mathrm{CC})$ & 352 & 135 & $\mathrm{I}^{\mathrm{a}}$ & 864 & $\mathrm{la}^{\mathrm{a}}$ & 197 & $\mathrm{l}^{\mathrm{a}}$ & 667 & $\mathrm{l}^{\mathrm{a}}$ \\
\hline Arg/Trp (CT) & 46 & 19 & $0.99(0.42-2.33)$ & 115 & $1.07(0.72-1.58)$ & 29 & $1.35(0.78-2.32)$ & 86 & $0.99(0.66-1.50)$ \\
\hline Trp/Trp (TT) & I & 2 & - & 4 & - & 1 & - & 3 & - \\
\hline Arg/Trp + Trp/Trp & 47 & 21 & $1.00(0.43-2.32)$ & 119 & $1.09(0.74-1.60)$ & 30 & $1.38(0.8 \mathrm{I}-2.36)$ & 89 & $1.01(0.68-1.52)$ \\
\hline Missing & & 1 & & & & & & & \\
\hline \multicolumn{10}{|l|}{$X R C C I \mathrm{Arg}^{280} \mathrm{His}$} \\
\hline $\operatorname{Arg} / \operatorname{Arg}(G G)$ & 381 & 145 & $f^{a}$ & 906 & $I^{a}$ & 207 & la & 699 & $\mathrm{l}^{\mathrm{a}}$ \\
\hline $\mathrm{Arg} / \mathrm{His}(\mathrm{GA})$ & 18 & 12 & $1.72(0.58-5.04)$ & 77 & $1.68(0.96-2.93)$ & 20 & $2.25(1.10-4.60)$ & 57 & $1.55(0.87-2.76)$ \\
\hline $\mathrm{His} / \mathrm{His}(\mathrm{AA})$ & 0 & 0 & - & 0 & - & 0 & - & 0 & - \\
\hline \multicolumn{10}{|l|}{$X R C C I \mathrm{Arg}^{399} \mathrm{Gln}$} \\
\hline $\operatorname{Arg} / \operatorname{Arg}(\mathrm{GG})$ & 148 & 63 & $\mathrm{I}^{\mathrm{a}}$ & 391 & $\mathrm{I}^{\mathrm{a}}$ & 100 & $I^{a}$ & 291 & $\mathrm{la}^{\mathrm{a}}$ \\
\hline $\operatorname{Arg} / G \ln (G A)$ & 187 & 70 & $0.74(0.4 I-I .33)$ & 443 & $0.82(0.62-1.08)$ & 95 & $0.67(0.46-0.99)$ & 348 & $0.87(0.65-1.16)$ \\
\hline $\mathrm{G} \ln / \mathrm{G} \ln (\mathrm{AA})$ & 64 & 24 & $0.91(0.42-1.98)$ & 149 & $0.88(0.61-1.29)$ & 32 & $0.65(0.38-1.13)$ & 117 & $0.96(0.65-1.42)$ \\
\hline $\mathrm{Arg} / \mathrm{Gln}+\mathrm{G} \ln / \mathrm{Gln}$ & 251 & 94 & $0.78(0.45-1.35)$ & 592 & $0.84(0.64-1.08)$ & 127 & $0.67(0.46-0.96)$ & 465 & $0.90(0.68-1.17)$ \\
\hline \multicolumn{10}{|l|}{ XRCC3 Thr 241 Met } \\
\hline Thr/Thr (CC) & 138 & 64 & $\mathrm{I}^{\mathrm{a}}$ & 380 & $I^{a}$ & 88 & $I^{a}$ & 292 & $\mathrm{I}^{\mathrm{a}}$ \\
\hline Thr/Met (CT) & 201 & 73 & $1.15(0.64-2.08)$ & 456 & $0.83(0.63-1.10)$ & 109 & $0.86(0.58-1.27)$ & 347 & $0.81(0.61-1.09)$ \\
\hline Met/Met (TT) & 60 & 20 & $1.09(0.46-2.55)$ & 147 & $0.92(0.63-1.35)$ & 30 & $0.84(0.48-1.47)$ & 117 & $0.97(0.65-1.45)$ \\
\hline Thr/Met + Met/Met & 261 & 93 & $1.14(0.64-2.01)$ & 603 & I.II (0.23-0.85) & 139 & $0.86(0.59-1.24)$ & 464 & $0.85(0.65-1.12)$ \\
\hline \multicolumn{10}{|l|}{ XPD Lys ${ }^{75} 1 \mathrm{Gln}$} \\
\hline Lys/Lys (AA) & 175 & 58 & $I^{a}$ & 364 & $\left.\right|^{a}$ & 87 & $I^{a}$ & 277 & $\mathrm{I}^{\mathrm{a}}$ \\
\hline Lys/Gln (AC) & 173 & 76 & $0.92(0.52-1.63)$ & 463 & $1.36(1.03-1.78)$ & 100 & I.II (0.75-I.63) & 363 & $1.43(1.07-1.89)$ \\
\hline $\mathrm{G} \ln / \mathrm{G} \ln (\mathrm{CC})$ & 50 & 22 & $0.84(0.36-1.95)$ & 155 & $1.55(1.05-2.30)$ & 40 & $1.38(0.80-2.37)$ & 115 & $1.56(1.03-2.36)$ \\
\hline Lys/Gln + Gln/Gln & 223 & 98 & $0.90(0.52-1.54)$ & 618 & $1.40(1.08-1.81)$ & 140 & $1.17(0.81-1.68)$ & 478 & $1.46(1.11-1.90)$ \\
\hline Missing & I & 1 & & 1 & & & & I & \\
\hline
\end{tabular}

a The genotype served as reference category

Genomic DNA was isolated from blood samples according to standard procedures [35] with minor modifications. In brief, whole blood samples (anticoagulated) was mixed with a threefold volume of lysis buffer $(155 \mathrm{mM}$ $\mathrm{NH}_{4} \mathrm{Cl}, 10 \mathrm{mM} \mathrm{KHCO}{ }_{3}, 1 \mathrm{mM}$ EDTA pH 7.4) and incubated at $4{ }^{\circ} \mathrm{C}$ for at least $30 \mathrm{~min}$. The lysate was then centrifuged, and pellet of intact leukocytes was resuspended in $10 \mathrm{ml} \mathrm{SE} \mathrm{buffer} \mathrm{(} 75 \mathrm{mM} \mathrm{NaCl}, 24 \mathrm{mM}$ EDTA pH 8.0) $500 \mu \mathrm{l}$ SDS (20\%) and $50 \mu \mathrm{l}$ Proteinase $\mathrm{K}(20 \mathrm{mg} / \mathrm{ml})$ and incubated overnight at $40^{\circ} \mathrm{C}$. After digestion, $3.5 \mathrm{ml} 6 \mathrm{M}$ $\mathrm{NaCl}$ was added to the lysate and the mixture was shaken vigorously and then centrifuged to pellet the cellular proteins. DNA in the supernatant was then precipitated with 2 volumes of absolute ethanol, washed in $70 \%$ ethanol and resuspended in TE buffer $(10 \mathrm{mM}$ Tris $\mathrm{HCl}, 0.1 \mathrm{mM}$ EDTA, pH 7.5).

Genotype analysis of the five single nucleotide polymorphisms (SNPs) of the DNA repair genes XRCC1, XRCC3 and XPD was carried out using the TaqMan allelic discrimination assay on a Sequence Detection System ABI 7000 (Applied Biosystems). The XRCC1 polymorphisms (XRCC1 Arg194Trp (rs\#1799782), XRCC1 Arg280His (rs\#25489), XRCC1 $\mathrm{Arg}^{399} \mathrm{Gln}$ (rs\#25487)) were determined in $12 \mu$ reactions containing $1 \times$ MasterMix, 200 $\mathrm{nM}$ of each probe, $900 \mathrm{nM}$ primers, and 50-100 ng of genomic DNA. Cycling conditions were as follows: $50^{\circ} \mathrm{C}$ for $2 \mathrm{~min}, 95^{\circ} \mathrm{C}$ for $10 \mathrm{~min}$, and 45 cycles of $95^{\circ} \mathrm{C}$ for 15 $\mathrm{s}$ and $60^{\circ} \mathrm{C}$ for $1 \mathrm{~min}$. Primers and probes are described in Table 2. The XRCC3 $\mathrm{Thr}^{241}$ Met (rs\#861539) and XPD Lys ${ }^{751} \mathrm{Gln}$ (rs\#1052559) were genotyped as described previously $[24,36]$. Controls were included in each run and repeated genotyping of a random $10 \%$ subset yielded 100 $\%$ identical genotypes.

SPSS (Statistical Packages for the Social Sciences) 12.0.1 for Windows was used for the statistic calculations. Odds ratios (OR) and $95 \%$ confidence intervals (CI) were calculated using binary logistic regression to assess the relationship between each polymorphism and the colorectal adenoma or carcinoma cases. Two separate ORs were calculated, one adjusted for age only (Table 3), and the other for age, gender, cigarette smoking (number of cigarette years) and alcohol consumption (units of alcohol per month) (Table 4). Due to missing data on cigarette smoking and alcohol consumption (67 controls, 51 carcinomas 
Table 4: Distributions of XRCCI Arg ${ }^{194}$ Trp, XRCCI Arg ${ }^{280} \mathrm{His}$, XRCCI Arg ${ }^{399} \mathrm{GIn}$, XRCC3 $\mathrm{Thr}^{241}$ Met and XPD Lys ${ }^{751}$ GIn genotypes and development of colorectal carcinomas and adenomas. ORs are adjusted for age, gender, cigarette smoking and alcohol consumption.

\begin{tabular}{|c|c|c|c|c|c|c|c|c|c|}
\hline Genotypes & Controls & Carcinomas & OR (95\% Cl) & Adenomas & OR $(95 \% \mathrm{Cl})$ & $\begin{array}{c}\text { High-risk } \\
\text { adenomas }\end{array}$ & OR $(95 \% \mathrm{Cl})$ & $\begin{array}{c}\text { Low-risk } \\
\text { adenomas }\end{array}$ & OR $(95 \% \mathrm{Cl})$ \\
\hline \multicolumn{10}{|l|}{ XRCCI Arg ${ }^{194}$ Trp } \\
\hline $\operatorname{Arg} / \operatorname{Arg}(\mathrm{CC})$ & 292 & 92 & $\mathrm{I}^{\mathrm{a}}$ & 734 & $\mathrm{I}^{\mathrm{a}}$ & 166 & $\mathrm{I}^{\mathrm{a}}$ & 568 & $\mathrm{I}^{\mathrm{a}}$ \\
\hline $\operatorname{Arg} / \operatorname{Trp}(\mathrm{CT})$ & 39 & 11 & $0.82(0.27-2.47)$ & 89 & $0.95(0.61-1.48)$ & 22 & $1.37(0.72-2.60)$ & 67 & $0.85(0.53-1.36)$ \\
\hline $\operatorname{Trp} / \operatorname{Trp}(\mathrm{TT})$ & I & 2 & - & 4 & - & 1 & - & 3 & - \\
\hline Arg/Trp + Trp/Trp & 40 & 13 & $0.84(0.28-2.48)$ & 93 & $0.96(0.62-1.49)$ & 23 & $1.35(0.71-2.56)$ & 70 & $0.87(0.55-1.38)$ \\
\hline Missing & & I & & & & & & & \\
\hline \multicolumn{10}{|l|}{ XRCCIArg ${ }^{280} \mathrm{His}$} \\
\hline $\operatorname{Arg} / \operatorname{Arg}(\mathrm{GG})$ & 319 & 100 & $\mathrm{I}^{\mathrm{a}}$ & 764 & $\left.\right|^{a}$ & 174 & $\mathrm{I}^{\mathrm{a}}$ & 590 & $\mathrm{I}^{\mathrm{a}}$ \\
\hline Arg/His (GA) & 13 & 6 & $1.48(0.29-7.48)$ & 63 & $2.30(1.19-4.46)$ & 15 & $3.82(1.59-9.18)$ & 48 & $2.07(1.05-4.10)$ \\
\hline $\mathrm{His} / \mathrm{His}(\mathrm{AA})$ & 0 & 0 & - & 0 & - & 0 & - & 0 & - \\
\hline \multicolumn{10}{|l|}{$X R C C I \mathrm{Arg}^{399} \mathrm{GIn}$} \\
\hline $\operatorname{Arg} / \operatorname{Arg}(G G)$ & 119 & 39 & $\mathrm{I}^{\mathrm{a}}$ & 326 & $\mathrm{I}^{\mathrm{a}}$ & 82 & $\mathrm{I}^{\mathrm{a}}$ & 244 & $\mathrm{I}^{\mathrm{a}}$ \\
\hline Arg/Gln (GA) & 159 & 51 & $0.87(0.43-1.78)$ & 371 & $0.74(0.54-1.01)$ & 79 & $\mathbf{0 . 5 9}(0.37-0.94)$ & 292 & $0.79(0.57-1.09)$ \\
\hline $\mathrm{G} \ln / \mathrm{G} \ln (\mathrm{AA})$ & 54 & 16 & $1.05(0.40-2.75)$ & 130 & $0.93(0.61-1.42)$ & 28 & $0.73(0.39-1.37)$ & 102 & $0.97(0.62-1.51)$ \\
\hline $\mathrm{Arg} / \mathrm{Gln}+\mathrm{G} \ln / \mathrm{G} \ln$ & 213 & 67 & $0.91(0.47-1.79)$ & 500 & $0.78(0.59-1.05)$ & 107 & $0.62(0.4 I-0.96)$ & 394 & $0.83(0.61-1.13)$ \\
\hline \multicolumn{10}{|l|}{ XRCC3 Thr ${ }^{241}$ Met } \\
\hline Thr/Thr (CC) & 116 & 45 & $\mathrm{I}^{\mathrm{a}}$ & 324 & $\mathrm{I}^{\mathrm{a}}$ & 70 & $\mathrm{I}^{\mathrm{a}}$ & 254 & $\mathrm{I}^{\mathrm{a}}$ \\
\hline Thr/Met (CT) & 169 & 48 & $1.18(0.57-2.42)$ & 380 & $0.83(0.61-1.14)$ & 91 & $1.06(0.67-1.68)$ & 289 & $0.78(0.57-1.08)$ \\
\hline Met/Met (TT) & 47 & 13 & $1.29(0.45-3.69)$ & 123 & $1.03(0.66-1.60)$ & 28 & $1.25(0.65-2.39)$ & 95 & $1.01(0.64-1.59)$ \\
\hline Thr/Met + Met/Met & 216 & 61 & $1.20(0.60-2.39)$ & 502 & $0.88(0.65-1.18)$ & 119 & $1.10(0.71-1.71)$ & 384 & $0.83(0.61-1.13)$ \\
\hline \multicolumn{10}{|l|}{ XPD Lys ${ }^{75} I^{\mathrm{G}} \mathrm{ln}$} \\
\hline Lys/Lys (AA) & 148 & 43 & $\mathrm{I}^{\mathrm{a}}$ & 300 & $I^{a}$ & 69 & $\mathrm{I}^{\mathrm{a}}$ & 231 & $\mathrm{I}^{\mathrm{a}}$ \\
\hline Lys/Gln (AC) & 142 & 47 & $0.81(0.40-1.67)$ & 390 & $1.35(0.99-1.83)$ & 86 & $1.27(0.81-2.01)$ & 304 & $1.33(0.97-1.84)$ \\
\hline $\mathrm{G} \ln / \mathrm{G} \ln (\mathrm{CC})$ & 41 & 15 & $1.00(0.38-2.62)$ & 136 & $1.66(1.07-2.58)$ & 34 & $1.59(0.85-2.99)$ & 102 & $1.61(1.02-2.54)$ \\
\hline $\mathrm{Lys} / \mathrm{G} \ln +\mathrm{G} \ln / \mathrm{G} \ln$ & 183 & 62 & $0.86(0.44-1.68)$ & 526 & $1.42(1.06-1.89)$ & 120 & $1.35(0.88-2.06)$ & 406 & $1.40(1.03-1.89)$ \\
\hline Missing & 1 & I & & & & & & 1 & \\
\hline
\end{tabular}

a The genotype served as reference category

and 156 adenomas) the number of case and controls used to calculate OR adjusted for age, gender, cigarette smoking and alcohol consumption (in Table 4) is reduced. Possible combined effects of the XRCC1 Arg ${ }^{280} \mathrm{His}$ and XRCC1 Arg ${ }^{399} \mathrm{Gln}$ polymorphisms were investigated in a two by three table (Table 5).

Given the allele frequency of polymorphism of the controls and assuming Hardy-Weinberg equilibrium, we had a $65 \%$ chance (at the $5 \%$ level) of detecting an OR of 2.25 for XRCC1 codon 280 heterozygotes among high-risk adenomas and $81 \%$ among low-risk adenomas. We had $60 \%$ chance of detecting an OR of 0.65 among carriers of the variant allele of XRCC1 codon 399 among high-risk adenomas and $81 \%$ among low-risk adenomas. For the XPD codon 751 polymorphism, we had $54 \%$ chance of detecting an OR of 1.36 and 1.55 among heterozygote and homozygote carriers among high-risk adenomas and $79 \%$ power among low-risk adenomas.

Haplotypes were estimated and ORs calculated using the Hplus program available online [37]. Hplus is a SNP analysis tool for performing haplotype estimation according to the distribution of genotypes in a population. Such haplotype-based methods should be used either for multiple SNPs within candidate genes or when selected SNPs are physically closed to each other [38]. We used this method to estimate haplotypes of three SNPs within the XRCC1 gene.

\section{Results}

The genotypic distributions of the five polymorphisms in the three DNA repair genes for both cases and controls are shown in Table 3. The frequencies for the XRCC1 194Trp allele, XRCC1 280His allele, XRCC1 399Gln allele, XRCC3 241Met allele and XPD 751Gln allele among the controls were respectively, 0.06, 0.02, 0.39, 0.40 and 0.34 . The genotype distributions were all in Hardy-Weinberg equilibrium and the distributions of the alleles in the control group are in agreement with those found in other Caucasian populations [9], and in other Scandinavian populations for the XRCC3 241Met allele and XPD $751 \mathrm{Gln}$ allele $[24,36]$. Tables 3 and 4 also presents the estimates of ORs of colorectal adenomas and carcinomas associated with the various XRCC1, XRCC3 and XPD polymorphisms. 
Table 5: Combinations of XRCCI Arg ${ }^{280} \mathrm{His}$ and $X R C C I \mathrm{Arg}^{399} \mathrm{Gln}$ polymorphisms and risk of colorectal carcinomas and adenomas. ORs are adjusted for age.

\begin{tabular}{|c|c|c|c|}
\hline \multirow[t]{2}{*}{ Case group } & \multicolumn{3}{|c|}{ OR $(95 \% \mathrm{Cl})\left(\mathbf{N}_{\text {case }} / \mathbf{N}_{\text {controls }}\right)$} \\
\hline & XRCCI $\operatorname{Arg}^{399} \mathrm{Gln}$ & XRCCI Arg ${ }^{280} \mathrm{His}$ & \\
\hline \multirow[t]{4}{*}{ Carcinomas } & & GG & GA \\
\hline & GG & I.0a $(56 / 137)$ & $1.93(0.44-8.49)(7 / 11)$ \\
\hline & GA & $0.76(0.4 \mid-1.38)(65 / 180)$ & $1.18(0.20-7.02)(5 / 7)$ \\
\hline & AA & $0.96(0.44-2.09)(24 / 64)$ & - \\
\hline \multirow[t]{4}{*}{ Adenomas } & & GG & GA \\
\hline & GG & $1.0 \mathrm{a}(34 \mathrm{I} / 137)$ & $1.75(0.85-3.63)(50 / 11)$ \\
\hline & GA & $0.85(0.64-1.13)(415 / 180)$ & $1.22(0.50-3.00)(27 / 7)$ \\
\hline & AA & $0.93(0.44-1.36)(149 / 64)$ & - \\
\hline \multirow[t]{4}{*}{ High-risk adenomas } & & GG & GA \\
\hline & GG & $1.0^{\mathrm{a}}(83 / 137)$ & $2.92(1.20-7.10)(17 / 11)$ \\
\hline & GA & $0.77(0.5 \mathrm{I}-1.15)(92 / 180)$ & $0.63(0.14-2.71)(3 / 7)$ \\
\hline & AA & $0.74(0.42-1.29)(32 / 64)$ & - \\
\hline \multirow[t]{4}{*}{ Low-risk adenomas } & & GG & GA \\
\hline & GG & $1.0^{a}(258 / 137)$ & $1.43(0.66-3.09)(33 / 11)$ \\
\hline & GA & $0.88(0.65-1.18)(324 / 180)$ & $1.47(0.59-3.66)(24 / 7)$ \\
\hline & AA & $1.00(0.67-1.48)(117 / 64)$ & \\
\hline
\end{tabular}

a The genotype served as a reference category

The XRCC1 280His allele was associated with an increased risk of adenomas with OR of 2.30 (95\% CI 1.19-4.46) (OR 3.82, 95\% CI 1.59-9.18 and OR 2.07, 95 $\%$ CI 1.05-4.10 for high- and low-risk adenomas, respectively). Among the carcinoma cases the same trend was observed although not significant. The XRCC1 399Gln allele showed a trend towards risk reduction for carcinomas and adenomas, reaching statistical significance only for the high-risk adenomas, OR of 0.62 (95\% CI $0.41-$ $0.96)$. There was no significant association between XRCC1 194Trp allele and risk of colorectal adenomas and carcinomas. The combination of the XRCC1 codon 280 and XRCC1 codon 399 polymorphisms showed a significant positive association for carriers of the XRCC1 codon 280 variant allele and XRCC1 codon 399 wild type allele, in the high-risk adenomas only, OR of 2.92 (95\% CI 1.20-7.10).

No significant association was found between the XRCC3 $\mathrm{Thr}^{241}$ Met polymorphism and risk of colorectal adenomas and carcinomas.

Further, no significant association was found between the XPD Lys ${ }^{751} \mathrm{Gln}$ polymorphism and colorectal cancer. There was, however, a significant association between the XPD 751Gln allele and risk of adenomas with OR of 1.42 (95\% CI 1.06-1.89). This association was limited to the low-risk adenoma group OR of 1.40 (95\% CI 1.03-1.89).
No statistical significant associations were found between the haplotypes estimated in the XRCC1 gene and adenoma or carcinoma risk (further data not shown).

\section{Discussion}

In this case-control study we investigated the role of polymorphisms, that result in amino acid substitution, of three DNA repair genes involved in NER, BER and HRR.

In this study we did not find an association between the $X P D$ Lys $^{751} \mathrm{Gln}$ polymorphism and colorectal carcinoma, but we did find an association between the XPD 751Gln allele and colorectal adenomas, especially with the lowrisk adenomas (OR 1.40, $95 \%$ CI 1.03-1.89). Lack of association with the cancer group and the high-risk adenoma group, may be due to small sample size. Another explanation for the observed association in the low-risk adenoma group could be that the polymorphism may play a role in regression of adenomas rather than progression to high-risk adenomas and cancer (advanced neoplasia). Although, it is generally assumed that adenomas grow into cancer or remain in the colon until death, epidemiological data suggests that less than $5 \%$ of adenomas may progress to carcinoma in a lifetime and spontaneous regression of adenomas has been reported [[39-41]]. Hofstad et al. [40] have reported that $60 \%$ of adenomas with diameters less than $10 \mathrm{~mm}$ stop growing or go into regression within 3 years of observation. In our material, $63 \%$ of cases with low-risk adenomas were hetero- or homozygous for this polymorphism. However, the char- 
acteristics of adenomas going into regression are not known.

Our results indicate that the XPD Lys $^{751} \mathrm{Gln}$ polymorphism may predispose slightly to development of colorectal adenomas or that the polymorphism may be of importance for arresting the adenoma-carcinoma sequence in the low-risk phase and facilitate regression of adenomas. Large prospective studies would be required to clarify this issue. XPD polymorphisms have been analyzed particularly in epidemiological studies on skin and smoking-related cancers and no obvious relationship has been found for these types of cancers. Mort et al. [14] and Yeh et al. [15] have reported no significant association between the XPD Lys ${ }^{751} \mathrm{Gln}$ polymorphism and colorectal cancer. To our knowledge no studies have been published on the association between XPD polymorphisms and colorectal adenomas.

We found no significant association between the XRCC1 194Trp allele and colorectal adenoma or carcinoma risk. This is not in agreement with the results reported by Abdel-Rahman et al. [12], but consistent with the results reported by Hong et al. [13].

In our study, the XRCC1 399Gln allele was associated with a slightly decreased risk of colorectal adenomas and carcinomas, although statistically significant only for the high-risk adenomas, (OR 0.62, 95\% CI 0.41-0.96). This protective role of the XRCC1 399Gln allele is in contrast to previous reports $[12,13]$ on this BER gene polymorphism and colorectal cancer risk. Previously, we reported a reduced risk of colorectal adenomas and cancer in association with another BER gene polymorphism, the OGG1 Ser ${ }^{326}$ Cys [42]. We have therefore tested the XRCC1 codon 399 and OGG1 codon 326 variant alleles in combination, but it showed no significant association with colorectal adenoma or cancer risk (OR 1.18, 95\% CI 0.38-3.68; OR $0.91,95 \%$ CI $0.54-1.52$ ) (further data not shown).

In this study we identified an association between the XRCC1 280His allele and risk of colorectal adenomas and carcinomas, but again, this increased risk was only significant for the adenomas (OR 2.30,95\% CI 1.19-4.46). As far as we know, the KAM study is the first reporting an association between the XRCC1 $\mathrm{Arg}^{280}$ His polymorphism and colorectal adenoma and carcinoma risk. There are few reports on this polymorphism. In 1999, Lunn et al. [43] examined the relationship of XRCC1 genotypes and different levels of aflatoxin B1-DNA adducts (51 controls and 69 cases), but no significant effects were observed for the XRCC1 280His allele. Recently, Hong et al. [13] reported an association between the 280 His allele and colorectal cancer in combination with the 194Arg allele and the 399Arg allele (OR 1.78, $95 \%$ CI 1.09-2.89).
Takanami et al. [44] have reported results suggesting that the XRCC1 $\mathrm{Arg}^{280} \mathrm{His}$ variant protein has an ineffective or reduced ability to localize a damaged site in the chromosome, thereby reducing the cellular BER/SSB repair efficiency. The variant 280 His allele may allow un-repaired SSBs to accumulate, thereby accelerating genomic instability which consequently increases the risk of carcinogenesis. This is supported by our findings of an association between a variant 280 His allele and high-risk adenomas. We found that the two polymorphisms XRCC1 Arg280His and XRCC1 Arg399Gln were linked such that the variant allele of XRCC1 codon 280 co-segregated with the wild type allele of XRCC1 codon $399(\mathrm{p}=0.045)$. When the XRCC1 Arg280His and XRCC1 Arg399Gln polymorphisms were combined, the effects of the polymorphisms appeared independently of each other. The variant carriers of XRCC1 codon 399 were not statistically significantly, but consistently, at decreased risk of cancer, whereas XRCC1 codon 280 heterozygotes were at increased risk of cancer.

No significant association was found between the XRCC3 $\mathrm{Thr}^{241}$ Met polymorphism and colorectal adenomas or carcinomas in our study. This XRCC3 codon 241 polymorphism has previously shown a significant association with colorectal cancer risk [14] (OR 1.52, 95\% CI 1.042.22) while in another study no association was detected [15]. One study reports no association between this XRCC3 polymorphism and colorectal adenoma risk [45]. High alcohol consumption has been linked to increased risk of colorectal neoplasia caused by an antifolate effect, resulting in uracil misincorporation into DNA and chromosomal breaks [46].

We have tested the combination of the XRCC3 codon 241 variant allele and alcohol consumption but it showed no significant association with colorectal adenoma or carcinoma risk (OR 1.00, 95\% CI 0.98-1.02; OR 0.96, 95\% CI 0.92-1.00) (further data not shown). We have also tested the interaction between each of the five DNA repair polymorphisms and cigarette smoking, but they showed no significant association with colorectal adenoma or carcinoma (further data not shown). These results are in agreement with other published studies $[45,47]$. To the best of our knowledge, contrary to genetic factors such as metabolic genetic polymorphisms, few studies suggest that the genetic polymorphisms of DNA repair genes may interact with environmental factors such as alcohol drinking and cigarette smoking $[3,9]$.

The divergence in results from different studies on XRCC1, $X R C C 3$ and XPD polymorphisms may be related to variation in carcinogenic exposure and ethnic origin of the studied populations. Too small sample size and/or the inadequate controlling for certain confounders such as 
age, gender, alcohol consumption and cigarette smoking may contribute to differing results. It is possible that some of the candidate genes only contribute to colorectal cancer development in combination with certain dietary and /or lifestyle factors. Interaction between various gene products may increase cancer risk. A combination of polymorphisms in these genes may have additive or synergistic effects. For polymorphisms not showing an obvious association with colorectal adenoma or cancer when studied separately, an association with colorectal adenoma or cancer is still possible in combination with other polymorphisms. We have tested the combination of the three polymorphisms in the XRCC1 gene but none of the estimated haplotypes showed a significant association with colorectal adenoma or carcinoma risk.

The design of this study is relatively strong because the controls were recruited from the same cohort as the adenoma and carcinoma cases. The CRC cases and controls have not been matched by age which may affect the results in a study. However, our controls have been screened and found polyp free and the risk of any of them having colon cancer at the time of inclusion is not very likely. The definition of polyp-free controls was based on a negative flexible sigmoidoscopy screening examination. It has been estimated that the risk of erroneously classifying individuals with proximal advanced neoplasia as neoplasia-free is less than $3 \%$ at flexible sigmoidoscopy $[48,49]$. Therefore, the risk of misclassification appears small, and it may only contribute to a type II statistical error, reducing the difference between case groups and controls. It cannot be excluded that the present findings are due to chance. The relatively small numbers of the CRC cases, and the low frequency of the variant allele for at least some of the polymorphisms limited our power to detect an assosiation with risk of adenomas and carcinomas.

\section{Conclusion}

In conclusion, our results suggest an increased risk for advanced colorectal neoplasia in individuals with XRCC1 Arg ${ }^{280} \mathrm{His}$ polymorphism and a reduced risk for persons with XRCC1 $\mathrm{Arg}^{399} \mathrm{Gln}$. The increased risk of having lowrisk adenomas in contrast to advanced neoplasia for individuals with $X P D$ Lys ${ }^{751} \mathrm{Gln}$ polymorphism may suggest a role in regression of adenomas and should be explored in prospective studies of in situ adenomas.

\section{Competing interests}

The author(s) declare that they have no competing interests.

\section{Authors' contributions}

CFS established the methods in the lab and performed the genotyping analysis of the XRCC1 and XRCC3 genes and prepared the first draft of the paper. She did the data anal- ysis. MS prepared samples for analysis. She also contributed to the manuscript and with advice on data analysis. PCH contributed with statistical advice. SA and IMBL contributed with the pathology of the cancer cases. EJ participated in the collection of blood samples and questionnaires from the cancer cases. ILH participated in collection and quality control of the questionnaires. UBV contributed with genotyping of the XPD gene and together with CFS, MS and EHK interpreted the results. EHK brought the idea of the KAM study and organized it. She was also responsible for the revisions of the manuscript. All authors discussed the results, contributed to interpretation of the results and the final manuscript.

\section{Acknowledgements}

This study was supported by the Norwegian Cancer Society (Grant numbers 51024/00I and E0I-085I00I), Telemark University College (Grant number 22069), the Norwegian Colorectal Cancer Prevention (NORCCAP) study (Grants from the Norwegian Cancer Society and the Department of Health and Social Affairs), with the aid of EXTRA funds from the Norwegian Foundation for Health and Rehabilitation (200I/2/0 I I0), Eastern Norway Regional Health Authority, the Danish Research Agency (Grant numbers 22-02-0356 and 2052-03-0016) and DRAGE, a grant from Danish Ministry of Health, Research Center for Environmental Health's Fund.

We thank Gunter Bock for collecting tumor tissues and Dr. Geir Hoff for critically reviewing the manuscript.

\section{References}

I. Fearon ER, Vogelstein B: A genetic model for colorectal tumorigenesis. Cell I990, 6 I(5):759-767.

2. Kinzler KW, Vogelstein B: Lessons from hereditary colorectal cancer. Cell 1996, 87(2): I59-170.

3. Potter JD: Colorectal cancer: molecules and populations. J Natl Cancer Inst 1999, 91 ( I I):916-932.

4. De Jong MM, Nolte IM, Te Meerman GJ, Van Der Graaf WT, De Vries EG, Sijmons RH, Hofstra RM, Kleibeuker JH: Low-penetrance Genes and Their Involvement in Colorectal Cancer Susceptibility. Cancer Epidemiol Biomarkers Prev 2002, I I (I I): I 332-I 352.

5. Stern MC, Umbach DM, Lunn RM, Taylor JA: DNA repair gene XRCC3 codon 24 I polymorphism, its interaction with smoking and XRCCI polymorphisms, and bladder cancer risk. Cancer Epidemiol Biomarkers Prev 2002, I I(9):939-943.

6. Ishibe N, Sinha R, Hein DW, Kulldorff M, Strickland P, Fretland AJ, Chow WH, Kadlubar FF, Lang NP, Rothman N: Genetic polymorphisms in heterocyclic amine metabolism and risk of colorectal adenomas. Pharmacogenetics 2002, I 2(2): |45- I 50.

7. de Boer JG: Polymorphisms in DNA repair and environmental interactions. Mutat Res 2002, 509(I-2):20I-2I0.

8. Shen MR, Jones IM, Mohrenweiser $\mathrm{H}$ : Nonconservative amino acid substitution variants exist at polymorphic frequency in DNA repair genes in healthy humans. Cancer Res 1998, 58(4):604-608.

9. Goode EL, Ulrich CM, Potter JD: Polymorphisms in DNA repair genes and associations with cancer risk. Cancer Epidemiol Biomarkers Prev 2002, I I(I 2): I5 |3-1530.

10. Vogel U, Nexo BA, Wallin H, Overvad K, Tjonneland A, RaaschouNielsen $O$ : No association between base excision repair gene polymorphisms and risk of lung cancer. Biochem Genet 2004, 42(I I-I 2):453-460.

II. Nexo BA, Vogel U, Olsen A, Ketelsen T, Bukowy Z, Thomsen BL, Wallin $\mathrm{H}$, Overvad $\mathrm{K}$, Tjonneland A: A specific haplotype of single nucleotide polymorphisms on chromosome $19 q / 3.2-3$ encompassing the gene RAI is indicative of post-menopausal breast cancer before age 55. Carcinogenesis 2003, 24(5):899-904. 
12. Abdel-Rahman SZ, Soliman AS, Bondy ML, Omar S, El-Badawy SA, Khaled HM, Seifeldin IA, Levin B: Inheritance of the I94Trp and the $399 \mathrm{GIn}$ variant alleles of the DNA repair gene $\mathrm{XRCCI}$ are associated with increased risk of early-onset colorectal carcinoma in Egypt. Cancer Lett 2000, I59(1):79-86.

13. Hong YC, Lee KH, Kim WC, Choi SK, Woo ZH, Shin SK, Kim H: Polymorphisms of XRCCI gene, alcohol consumption and colorectal cancer. Int J Cancer 2005.

14. Mort R, Mo L, McEwan C, Melton DW: Lack of involvement of nucleotide excision repair gene polymorphisms in colorectal cancer. BrJ Cancer 2003, 89(2):333-337.

15. Yeh C-C, Sung F-C, Tang R, Chang-Chieh C, Hsieh L-L: Polymorphisms of the XRCCI, XRCC3, \& XPD genes, and colorectal cancer risk: a case-control study in Taiwan. BMC Cancer 2005 5(I): 12 .

16. Ratnasinghe D, Yao SX, Tangrea JA, Qiao YL, Andersen MR, Barrett MJ, Giffen CA, Erozan Y, Tockman MS, Taylor PR: Polymorphisms of the DNA repair gene $X R C C I$ and lung cancer risk. Cancer Epidemiol Biomarkers Prev 2001, 10(2): I 19-123.

17. Moullan N, Cox DG, Angele S, Romestaing P, Gerard JP, Hall J: Polymorphisms in the DNA repair gene $X R C C I$, breast cancer risk, and response to radiotherapy. Cancer Epidemiol Biomarkers Prev 2003, I2(II Pt I): I|68-II74.

18. Griffin CS, Simpson PJ, Wilson CR, Thacker J: Mammalian recombination-repair genes XRCC2 and XRCC3 promote correct chromosome segregation. Nat Cell Biol 2000, 2( I 0):757-76I.

19. Cui X, Brenneman M, Meyne J, Oshimura M, Goodwin EH, Chen DJ: The $X R C C 2$ and $X R C C 3$ repair genes are required for chromosome stability in mammalian cells. Mutat Res 1999, 434(2):75-88

20. Matullo G, Palli D, Peluso M, Guarrera S, Carturan S, Celentano E, Krogh V, Munnia A, Tumino R, Polidoro S, Piazza A, Vineis $P$. $X R C C I, X R C C 3, X P D$ gene polymorphisms, smoking and (32)P-DNA adducts in a sample of healthy subjects. Carcinogenesis 200I, 22(9): | 437-| 445.

21. Kuschel B, Auranen A, McBride S, Novik KL, Antoniou A, Lipscombe JM, Day NE, Easton DF, Ponder BA, Pharoah PD, Dunning A: Variants in DNA double-strand break repair genes and breast cancer susceptibility. Hum Mol Genet 2002, I I ( I 2): | 399- | 407

22. Jacobsen NR, Raaschou-Nielsen O, Nexo B, Wallin H, Overvad K Tjonneland $A$, Vogel U: XRCC3 polymorphisms and risk of lung cancer. Cancer Lett 2004, 213(I):67-72.

23. Winsey SL, Haldar NA, Marsh HP, Bunce M, Marshall SE, Harris AL Wojnarowska $\mathrm{F}$, Welsh $\mathrm{KI}$ : A variant within the DNA repair gene XRCC3 is associated with the development of melanoma skin cancer. Cancer Res 2000, 60(20):56|2-56|6.

24. Jacobsen NR, Nexo BA, Olsen A, Overvad K, Wallin H, Tjonneland $A$, Vogel U: No association between the DNA repair gene XRCC3 T24IM polymorphism and risk of skin cancer and breast cancer. Cancer Epidemiol Biomarkers Prev 2003, I 2(6):584-585.

25. Lindahl T, Karran P, Wood RD: DNA excision repair pathways. Curr Opin Genet Dev 1997, 7(2): I58-169.

26. Braithwaite E, Wu X, Wang Z: Repair of DNA lesions: mechanisms and relative repair efficiencies. Mutat Res I999, 424(I2):207-219.

27. Flejter WL, McDaniel LD, Johns D, Friedberg EC, Schultz RA: Correction of xeroderma pigmentosum complementation group D mutant cell phenotypes by chromosome and gene transfer: involvement of the human ERCC2 DNA repair gene. Proc Natl Acad Sci U S A 1992, 89( I):26I-265.

28. de Laat WL, Jaspers NG, Hoeijmakers JH: Molecular mechanism of nucleotide excision repair. Genes Dev 1999, I3(7):768-785.

29. Sung P, Bailly V, Weber C. Thompson LH, Prakash L, Prakash S: Human xeroderma pigmentosum group $D$ gene encodes a DNA helicase. Nature 1993, 365(6449):852-855.

30. Coin F, Bergmann E, Tremeau-Bravard A, Egly JM: Mutations in XPB and XPD helicases found in xeroderma pigmentosum patients impair the transcription function of TFIIH. Embo 1999, I 8(5): 1357-1366.

31. Benhamou S, Sarasin A: ERCC2/XPD gene polymorphisms and cancer risk. Mutagenesis 2002, I7(6):463-469.

32. Benhamou S, Sarasin A: ERCC2 IXPD gene polymorphisms and lung cancer: a HuGE review. Am J Epidemiol 2005, I6 I (I): I- 14.

33. Gondal G, Grotmol T, Hofstad B, Bretthauer M, Eide T], Hoff G: The Norwegian Colorectal Cancer Prevention (NORCCAP) screening study: baseline findings and implementations for clinical work-up in age groups $\mathbf{5 0 - 6 4}$ years. Scand J Gastroenterol 2003, 38(6):635-642.

34. ClinicalTrials.gov [http://www.clinicaltrials.gov]

35. Miller SA, Dykes DD, Polesky HF: A simple salting out procedure for extracting DNA from human nucleated cells. Nucleic Acids Res 1988, 16(3): 1215

36. Vogel U, Laros I, Jacobsen NR, Thomsen BL, Bak H, Olsen A, Bukowy Z, Wallin H, Overvad K, Tjonneland A, Nexo BA, Raaschou-Nielsen O: Two regions in chromosome $19 \mathrm{q} / 3.2-3$ are associated with risk of lung cancer. Mutat Res 2004, 546(I-2):65-74.

37. Hplus [http://age.fhcrc.org/hplus]

38. Zhao LP, Li SS, Khalid N: A method for the assessment of disease associations with single-nucleotide polymorphism haplotypes and environmental variables in case-control studies. Am J Hum Genet 2003, 72(5): $1231-1250$.

39. Hoff G, Foerster A, Vatn MH, Sauar J, Larsen S: Epidemiology of polyps in the rectum and colon. Recovery and evaluation of unresected polyps 2 years after detection. Scand J Gastroenterol 1986, 2 I (7):853-862

40. Hofstad B, Vatn MH, Andersen SN, Huitfeldt HS, Rognum T, Larsen S, Osnes M: Growth of colorectal polyps: redetection and evaluation of unresected polyps for a period of three years. Gut 1996, 39(3):449-456.

4I. Loeve F, Boer R, Zauber AG, Van Ballegooijen M, Van Oortmarssen G], Winawer SJ, Habbema JD: National Polyp Study data: evidence for regression of adenomas. Int J Cancer 2004, I I I(4):633-639.

42. Hansen R, Saebo M, Skjelbred CF, Nexo BA, Hagen PC, Bock G, Bowitz Lothe IM, Johnson E, Aase S, Hansteen IL, Vogel U, Kure EH: GPX Prol 98Leu and OGGI Ser326Cys polymorphisms and risk of development of colorectal adenomas and colorectal cancer. Cancer Lett 2005.

43. Lunn RM, Langlois RG, Hsieh LL, Thompson CL, Bell DA: XRCCI polymorphisms: effects on aflatoxin $B I-D N A$ adducts and glycophorin A variant frequency. Cancer Res 1999 , 59( I I):2557-256I.

44. Takanami T, Nakamura J, Kubota Y, Horiuchi S: The Arg280His polymorphism in $\mathrm{X}$-ray repair cross-complementing gene I impairs DNA repair ability. Mutat Res 2005, 582(I-2): I 35- 145

45. Tranah GJ, Giovannucci E, Ma J, Fuchs C, Hankinson SE, Hunter DJ: XRCC2 and XRCC3 polymorphisms are not associated with risk of colorectal adenoma. Cancer Epidemiol Biomarkers Prev 2004, I3(6): 1090-1091.

46. Giovannucci E, Stampfer MJ, Colditz GA, Rimm EB, Trichopoulos D, Rosner BA, Speizer FE, Willett WC: Folate, methionine, and alcohol intake and risk of colorectal adenoma. J Natl Cancer Inst 1993, 85( I I):875-884.

47. Jin MJ, Chen K, Song L, Fan CH, Chen Q, Zhu YM, Ma XY, Yao KY: The association of the DNA repair gene XRCC3 Thr24IMet polymorphism with susceptibility to colorectal cancer in a Chinese population. Cancer Genet Cytogenet 2005, 163(1):38-43.

48. Lieberman DA, Weiss DG, Bond JH, Ahnen DJ, Garewal $H$, Chejfec G: Use of colonoscopy to screen asymptomatic adults for colorectal cancer. Veterans Affairs Cooperative Study Group 380. N Engl J Med 2000, 343(3): 162-168.

49. Imperiale TF, Wagner DR, Lin CY, Larkin GN, Rogge JD, Ransohoff DF: Risk of advanced proximal neoplasms in asymptomatic adults according to the distal colorectal findings. N Engl J Med 2000, 343(3): 169-174

\section{Pre-publication history}

The pre-publication history for this paper can be accessed here:

http://www.biomedcentral.com/1471-2407/6/67/prepub 